\title{
Peningkatan Kemampuan Menulis Karangan Berdasarkan Pengalaman Pada Siswa Kelas V SD Inpres 55 Kabupaten Sorong Semester II Tahun Pelajaran 2015/2016
}

\author{
Katharina Bame \\ SD Inpres 55 Kabupaten Sorong \\ Email: bame_katharina@ymail.com
}

\begin{abstract}
The aim of the research is to decribe the improvement of students' ability in writing composition text based on experience by using task method at the fifth grade students of SD Inpres 55 Sorong Regency. The model used in this research was Kemmis and Mac Taggart cycle, which covered cycle I and cycle II. Each cycle consisted of four components, they were planning, action, observation and reflection. Based on the result, it can be inferred that revision the assignment by using task method could improve students' ability in writing composition text based on experience at the fifth grade students of SD Inpres 55 Sorong Regency academic year 2015/2016. The improvement could be seen from the average score of every students which improved from cycle I to cycle II and there was also an improvement of the average score of clasical completeness above the Minimum Completeness Criteria (KKM). The learning situation got better. Students' motivation and coorporation in groups increased. Students also felt more happy and comfortable in the learning process. The improvement of the teacher's learning planning was also apparent from cycle I to cycle II.
\end{abstract}

Keywords: ability improvement, writing composition text based on experience

Abstrak: Tujuan penelitian ini adalah untuk mendiskripsikan peningkatan kemampuan menulis Karangan berdasarkan pengalaman dengan metode tugas siswa kelas V SD Inpres 55 Kabupaten Sorong. Model yang digunakan dalam penelitian ini adalah siklus Kemmis dan Mac.Taggart, meliputi siklus I dan siklus II yang terdiri atas empat komponen yaitu perencanaan, tindakan, observasi dan refleksi. Berdasarkan hasil penelitian tindakan kelas dapat disimpulkan bahwa tindakan perbaikan pembelajaran metode tugas telah mampu meningkatkan kemampuan menulis karangan berdasarkan pengalaman pada siswa kelas V SD Inpres 55 Kabupaten Sorong tahun pembelajaran 2015/2016. Peningkatan tampak pada nilai rata-rata ketuntasan perorangan siswa pada siklus I meningkat ke siklus II di atas KKM dan peningkatan terjadi pada nilai ratarata ketuntasan klasikal di atas KKM. Dalam kegiatan proses belajar mengajar suasana belajar juga tampak meningkat pada motivasi dan kerjasama dalam kelompok. Siswa merasa lebih senang dan nyaman. Peningkatan juga nampak pada perencanaan pelaksanaan pembelajaran guru dari siklus I ke siklus II yang dinyatakan lebih baik.

Kata Kunci: peningkatan kemampuan, menulis Karangan berdasarkan pengalaman

\section{Pendahuluan}

Mata Pelajaran bahasa Indonesia sebagai salah satu mata pelajaran pokok yang sering disajikan sebagai tolak ukur dalam ujian sekolah bestandar nasional, mengalami perluasan. Tujuan pembelajaran Bahasa Indonesia di sekolah tidak sekedar berwujud materi-materi pembelajaran yang bersifat teoritis, namun lebih ditekankan pada aspek penggunaan dalam wujud kemampuan (kompetensi) untuk berbahasa Indonesia secara baik. Pembelajaran bahasa Indonesia lebih diarahkan untuk meningkatkan kemampuan siswa untuk berkomunikasi secara lisan maupun tertulis. 
Potensi untuk menulis dapat dipupuk sejak dini untuk melatih kreativitasnya dalam menuangkan segala ide dan gagasannya. Tidak menutup kemungkinan jika diantara siswa menjadi penulis terkenal. Dalam standar umum pemerolehan pelajaran di sekolah, seorang siswa akan dianggap kurang sempurna memiliki pengetahuan dan pengalaman jika tidak pernah diimbangi dengan kemampuan menulis atau menuangkan pengetahuan dan pengalaman dalam bentuk tulisan.

Jenis menulis khususnya mengarang berdasarkan pengalaman bagi siswa SD mempunyai fungsi pula untuk mengembangkan kreativitas dan daya imajinasi dalam mengimajinasi bentuk tulisan untuk menuangkan gagasan maupun ide. Siswa SD kemampuan berpikir untuk mengembangkan imajinasinya mulai tumbuh. Hal ini tentu saja terkait dengan tumbuhnya tingkat kesadaran, logikanya untuk berpikir secara rasional masuk akal sehingga dalam mengungkapkan berbagai ide, gagasan atau pendapat pun telah mulai terperinci, bahkan kadang-kadang sudah disertai dengan berbagai bukti lebih aktual. Tentu hal ini merupakan potensi dan prestasi khusus yang dapat dikembangkan dalam pembelajaran menulis.

Berkaitan dengan latar belakang masalah tersebut, tujuan penelitian ini adalah untuk mendiskripsikan peningkatan kemampuan menulis karangan berdasarkan pengalaman dengan metode tugas siswa kelas V SD Inpres 55 Kabupaten Sorong.

\section{Metode Penelitian}

\subsection{Subjek Penelitian}

Penelitian dilakukan pada siswa kelas V SD Inpres 55 Kabupaten Sorong Tahun Pelajaran 2015/2016.

\subsection{Prosedur Penelitiaan}

Penelitian ini dilakukan dengan berkolaborasi bersama satu orang guru, menggunakan jam kegiatan belajar mengajar. Model yang digunakan dalam penelitain ini adalah siklus Kemmis dan Mac.Taggart. Model ini terdiri atas empat komponen yaitu perencanaan, tindakan, observasi dan refleksi. Desain tindakan pembelajaran dilaksanakan dalam dalam 2 siklus sebagai berikut :

a. Siklus I

1) Perencanaan 
Perencanaan dilakukan dengan instrumen: 1) Penyusunan Rencana Perbaikan Pembelajaran (RPP), 2) Penyusunan tes evaluasi akhir, 3) Pedoman observasi (pengamatan) dalam proses belajar mengajar (baik untuk guru maupun siswa), 4) Pedoman wawancara dengan siswa, lembar catatan anekdot siswa. Hal ini dilakukan bersama guru kolaborator.

2) Pelaksanaan tindakan dilakukan sebagai berikut:

a) Guru menyampaikan tujuan pembelajaran

b) Guru membagi beberapa majalah atau koran yang ada tulisan Karangan berdasarkan pengalamannya.

c) Guru memberi tugas siswa mencari contoh tulisan Karangan berdasarkan pengalaman di majalah/ koran

d) Siswa mencari contoh tulisan Karangan berdasarkan pengalaman di majalah/koran

e) Siswa berdiskusi dengan teman sebangku tentang definisi dan ciri-ciri menulis Karangan berdasarkan pengalaman

f) Guru bersama siswa menyimpulkan definisi dan ciri-ciri menulis Karangan berdasarkan pengalaman.

g) Guru menjelaskan ulang beberapa contoh hasil tulisan Karangan berdasarkan pengalaman

h) Guru memberi tugas menulis Karangan berdasarkan pengalaman

i) Guru berkeliling mengecek siswa

j) Guru memberikan evaluasi akhir

k) Guru menganalisis hasil evaluasi

3) Observasi/Pengamatan

Pengamatan dilakukan untuk memberikan evaluasi-refleksi. Pengamatan dilakukan secara kolaboratif antara peneliti dengan siswa menggunakan instrumen monitoring yang telah direncanakan, diantaranya:

a) Motivasi siswa mengikuti pembelajaran

b) Kerja sama dalam kelompok

c) Kecepatan siswa dalam membaca pemahaman

d) Kegiatan guru dalam menggunakan metode pembelajaran

e) Kegiatan guru dalam menyampaikan tujuan pembelajaran

f) Kegiatan guru dalam memberikan tugas 
g) Kegiatan guru dalam memberikan motivasi kepada siswa

h) Kegiatan guru dalam pengelolaan kelas

4) Evaluasi-Refleksi

Semua temuan dicatat oleh guru yang mengajar ataupun guru kolaborator. Kemudian hasil temuan tersebut didiskusikan kembali untuk mengambil kesimpulan pada evaluasirefleksi untuk menentukan tindakan-tindakan pada siklus berikutnya.

b. Siklus II

1) Perencanaan

Perencanaan pada tahap dua dilakukan dengan instrumen tetap mengacu pada siklus I yaitu : 1) Rencana Perbaikan Pembelajaran/RPP, 2) Penyusunan tes evaluasi akhir, 3) Pedoman observasi (pengamatan) dalam proses belajar mengajar (baik guru maupun siswa), 4) Pedoman wawancara dengan siswa, lembar catatan-catatan anekdot siswa.

2) Pelaksanaan

Pelaksanaan tindakan ini dilakukan dengan menyempurnakan siklus I dengan lebih memberi penekanan pada kemampuan siswa. Pelaksanaan tindakan ini dilakukan sebagai berikut:

a) Guru menyampaikan tujuan pembelajaran

b) Guru menegaskan kembali tentang pengertian dan ciri-ciri menulis karangan berdasarkan pengalaman

c) Guru membagi tulisan karangan berdasarkan pengalaman dari beberapa majalah /koran yang ada.

d) Guru memberi tugas siswa mencari fakta dan bukti yang menguatkan contoh tulisan Karangan berdasarkan pengalaman yang dibagi

e) Siswa mencari contoh lain tulisan karangan berdasarkan pengalaman dari beberapa majalah/ koran

f) Guru memberi tugas menulis karangan berdasarkan pengalaman

g) Guru berkeliling mengamati siswa ketika melaksanakan tugas

h) Guru memberikan evaluasi akhir

i) Guru menganalisis hasil evaluasi 


\section{3) Observasi/ pengamatan}

Pengamatan dilakukan untuk memberikan evaluasi refleksi kembali dari proses perbaikan yang telah dilakukan. Pengamatan tetap dilakukan berkolaboratif dengan guru lain, menggunakan instrumen monitoring yang telah direncanakan diantaranya:

a) Motivasi siswa mengikuti pembelajaran

b) Kerjasama dengan kelompok

c) Kecepatan siswa dalam membaca pemahaman

d) Kegiatan guru dalam menggunakan metode pembelajaran

e) Kegiatan guru dalam menyampaikan tujuan pembelajaran

f) Kegiatan guru dalam memberikan tugas

g) Kegiatan guru dalam memberikan motivasi siswa untuk bertanya

h) Kegiatan pengelolaan guru berkeliling mengamati siswa ketika melaksanakan tugas.

i) Evaluasi

\section{4) Refleksi}

Semua temuan dicatat oleh guru yang mengajar ataupun guru kolaborator. Hasil tersebut didiskusikan kembali untuk mengambil kesimpulan pada evaluasi-refleksi untuk menentukan tindakan-tindakan pada siklus berikutnya hingga mencapai tujuan akhir yang diharapkan.

Instrumen penelitian sangat terkait dengan jenis data yang akan diambil, yaitu berupa 1) data hasil belajar siswa dilakukan dengan tes membaca. 2) data situasi belajar mengajar dilakukan dengan pengamatan dan wawancara. Serta 3) data keterkaitan perencanaan dengan pelaksanaan tindakan dilakukan dengan pengamatan dan wawancara. Data yang terkumpul ditabulasi menggunakan teknik diskriptif analitik, dengan penjelasan sebagai berikut : a) pengembangan gagasan nilai maksimal 40, b) diksi (pilihan kata) nilai maksimal 30, dan c) EYD nilai maksimal 30.

Data dari teknik non tes (observasi, angket, jurnal guru, dan wawancara) diklasifikasikan sebagai data kualitatif maka data diinterprestasikan, untuk kemudian dihubungkan dengan data kuantitatif sebagai dasar untuk mendiskripsikan keberhasilan pelaksanaan pembelajaran. Dengan ditandai semakin meningkatnya kemampuan ketrampilan, nilai dan perubahan perilaku serta sikap siswa. 
Analisis data dilakukan dari siklus I menuju siklus II atau siklus seterusnya sesuai dengan target yang diharapkan. Analisis ini menggunakan teknik kuantitatif dan kualitatif berdasarkan jenis datanya. Data yang berupa angka-angka ditafsirkan menggunakan analisis kuantitatif. Analisis tersebut dilakukan untuk menganalisis data yang berupa skor hasil tes kemampuan menulis Karangan berdasarkan pengalaman dengan nilai minimal ketuntasan belajar sebesar 6,5 berjumlah $85 \%$.

Analisis kualitatif digunakan sebagai teknik tambahan untuk menjelaskan datadata yang telah dikuantitatifkan, yaitu perasaan senang, antusias, perhatian, aktif berani dan lain-lain).

\section{Hasil Penelitian dan Pembahasan}

\subsection{Hasil Penelitian}

Hasil penelitian yang dilakukan pada siswa kelas V SD Inpres 55 Kabupaten Sorong Pelajaran 2015/2016 terkait pembelajaran kemampuan menulis karangan berdasarkan pengalaman dengan tindakan perbaikan pembelajaran melalui metode tugas, yang didasarkan prosedur dalam siklus I dan II, secara lengkap dijabarkan sebagai berikut.

a. Siklus I

Tabel 1. Hasil kemampuan menulis karangan berdasarkan pengalaman Siklus I

\begin{tabular}{|c|c|c|c|c|}
\hline No. & Skor Nilai & Keterangan & Frekuensi & Persen(\%) \\
\hline 1. & $0-44$ & Sangat Buruk & 0 & 0 \\
\hline 2 & $45-45$ & Buruk & 0 & 0 \\
\hline 3. & $55-64$ & Kurang & 6 & 30 \\
\hline 4. & $65-74$ & Cukup & 6 & 30 \\
\hline 5. & $75-84$ & Baik & 5 & 25 \\
\hline 6. & $85-100$ & Sangat Baik & 3 & 15 \\
\hline \multicolumn{3}{|c|}{ Total } & 20 & 100 \\
\hline
\end{tabular}

Berdasarkan tabel 1. dari sejumlah 20 siswa dapat diketahui yang mencapai skor sangat baik sejumlah 3 siswa atau sebesar 15\%. Siswa yang mencapai skor baik sebanyak 5 siswa, atau sebesar 25\% dalam kategori baik. Siswa yang mencapai skor cukup sebanyak 6 siswa berarti 30\% dalam kategori kurang.

Hasil belajar rata-rata nilai kemampuan menulis karangan berdasarkan pengalaman siswa pada siklus I tersebut berdasarkan indikator keberhasilan sesuai 
Kriteria Ketuntasan Minimal (KKM) individual yaitu sebesar 65, dengan keberhasilan klasikal siswa yang mempunyai nilai 65 berjumlah $85 \%$ adalah sebagai berikut : (1) daya serap perseorangan sesuai KKM belum tercapai dengan skor nilai 72,65 sudah di atas skor 65. Dengan demikian ketuntasan individu telah tercapai; sedangkan (2) daya serap klasikal kelas belum tercapai yaitu sebesar 70\%, atau dengan kata lain masih ada sekitar 30\% siswa yang mempunyai nilai di bawah 65 .

Dari hasil tes menulis karangan berdasarkan pengalaman pada siklus I ini secara umum masih perlu diadakan perbaikan. Pembimbingan guru harus lebih inensif agar kemampuan sisa dalam menulis semakin meningkat kualitasnya. Beberapa siswa yang masih memperoleh nilai di bawah KKM harus lebih banyak diberikan perhatian.

Berdasarkan hasil pengamatan hasil KBM diketahui bahwa : (1) motivasi siswa mengikuti pembelajaran ; (2) keberanian siswa dalam mengungkapkan ide dan gagasan; (3) mobilitas keaktifan siswa dalam mengungkapkan ide dan bertanya; dan (4) tanggung jawab siswa dalam menilai dan menanggapi pekerjaan teman masih dalam kategori cukup, sehingga membutuhkan perbaikan dalam rencana siklus berikutnya, dari hasil siklus ini diperoleh temuan bahwa mobilitas dan cara mengajar ini masih cenderung kaku, guru harus lebih aktif memotivasi dengan memberikan pujian atau ketika ada siswa yang bertanya hendaknya diumpanbalikkan ke siswa kembali. Oleh karena itu, penguatan guru dalam pembelajaran pada siklus berikutnya perlu ditingkatkan.

Data keterkaitan perencanaan dengan pelaksanaan tindakan diperoleh dari guru kolaborator. Belum seluruhnya sesuai dengan perencanaan yang ditulis. Guru masih sering terpaku pada alokasi waktu belum memperhitungkan tingkat keterlibatan siswa dakam pembelajaran. Apersepsi guru juga harus lebih difokuskan sehingga mampu mengukur pengetahuan dasar siswa. Manajemen waktu sudah sesuai dengan waktu sudah sesuai dengan waktu yang direncanakan. Dengan demikian, untuk perbaikan pada pelaksanaan tindakan pada siklus II, guru perlu lebih detail memahami perencanaan yang telah dibuat. 
b. Siklus II

Tabel 2. Hasil kemampuan menulis Karangan berdasarkan pengalaman Siklus I

\begin{tabular}{ccccc}
\hline No. & Skor Nilai & Keterangan & Frekuensi & Persen(\%) \\
\hline 1 & $0-44$ & Sangat Buruk & 0 & 0 \\
2 & $45-45$ & Buruk & 0 & 0 \\
3 & $55-64$ & Kurang & 0 & 0 \\
4 & $65-74$ & Cukup & 4 & 20 \\
5 & $75-84$ & Baik & 8 & 40 \\
6 & $85-100$ & Sangat Baik & 8 & 40 \\
\hline & Total & & 20 & 100 \\
\hline
\end{tabular}

Diketahui jumlah siswa 20 siswa, yang mencapai skor sangat baik sejumlah 8 siswa (40\%). Siswa yang mencapai skor baik sebanyak 8 siswa yang (40\%). Sedangkan siswa yang mencapai skor cukup sebanyak 4 siswa (20\%).

Hasil pengamatan dalam KBM pada siklus II juga diketahui ada peningkatan yang cukup signifikan yaitu pada aspek : 1) motivasi siswa mengikuti pembelajaran, 2) keberanian siswa dalam mengungkapkan ide dan gagasan, 3) mobilitas keaktifan siswa dalam mengungkapkan ide dan bertanya, 4) tanggungjawab siswa dalam menilai dan menanggapi pertanyaan teman, dari kategori cukup menjadi baik. Usaha yang ditempuh guru dalam perbaikan pada siklus II dapat menambah mobilitas dan mengubah cara mengajar yang telah mampu memotivasi keaktifan siswa dalam kegiatan belajar mengajar.

Hasil kemampuan menulis karangan berdasarkan pengalaman siswa pada siklus II menunjukkan hasil yang lebih baik dengan peningkatan yang signifikan. Berdasarkan KKM yang ditentukan diketahui bahwa nilai rata-rata ketuntasan perorangan siswa pada siklus II meningkat di atas KKM dan peningkatan juga terjadi pada nilai rata-rata ketuntasan klasikal di atas KKM.

Berdasarkan data keterkaitan perencanaan dengan pelaksanaan tindakan diperoleh dari guru kolaborator, bahwa manajemen waktu sudah sesuai dengan waktu yang direncanakan. Namun guru masih sering terpaku dengan waktu belum memperhitungkan tingkat keterlibatan sisa dalam pembelajaran. Apersepsi guru juga harus lebih difokuskan sehingga mampu mengukur pengtahuan dasar siswa. 


\subsection{Pembahasan}

Berdasarkan hasil pengamatan hasil KBM pada siklus I, diketahui bahwa : (1) motivasi siswa mengikuti pembelajaran ; (2) keberanian siswa dalam mengungkapkan ide dan gagasan; (3) mobilitas keaktifan siswa dalam mengungkapkan ide dan bertanya; dan (4) tanggung jawab siswa dalam menilai dan menanggapi pekerjaan teman masih dalam kategori cukup, sehingga membutuhkan perbaikan dalam rencana siklus berikutnya, dari hasil siklus ini diperoleh temuan bahwa mobilitas dan cara mengajar ini masih cenderung kaku, guru harus lebih aktif memotivasi dengan memberikan pujian atau ketika ada siswa yang bertanya hendaknya diumpanbalikkan ke siswa kembali. Oleh karena itu, penguatan guru dalam pembelajaran pada siklus berikutnya perlu ditingkatkan.

Sementara itu, data keterkaitan perencanaan dengan pelaksanaan tindakan diperoleh dari guru kolaborator. Belum seluruhnya sesuai dengan perencanaan yang ditulis. Guru masih sering terpaku pada alokasi waktu belum memperhitungkan tingkat keterlibatan siswa dakam pembelajaran. Apersepsi guru juga harus lebih difokuskan sehingga mampu mengukur pengetahuan dasar siswa. Manajemen waktu sudah sesuai dengan waktu sudah sesuai dengan waktu yang direncanakan. Dengan demikian, untuk perbaikan pada pelaksanaan tindakan pada siklus II, guru perlu lebih detail memahami perencanaan yang telah dibuat.

Selanjutnya, hasil pada siklus II ini secara umum sudah sangat bagus. Tetapi guru harus selalu memperhatikan perencanaan pembelajaran yang dirancang sehingga pelaksanaan tindakan yang dilakukan tidak menyimpang dari target yang tentukan, terutama dalam pengaturan waktu, metode yang telah dirancang secara variatif dan kreatif.

Tindakan perbaikan pembelajaran melalui metode tugas secara umum telah mampu mengkondisikan siswa untuk lebih siap dan senang dalam pembelajaran. engan metode tugas siswa akan lebih terangsang untuk aktif belajar, maka tugas bisa diberikan secara individual maupun kelompok tugas dapat diberikan di sekolah, di rumah maupun di perpustakaan. Dengan metode tugas akan tercipta interaksi edukatif antara guru dan siswa. Guru berperan sebagai penggerak dan pembimbing sedangkan siswa berperan sebagai penerima dan dibimbing. 


\section{Kesimpulan dan Saran}

\subsection{Kesimpulan}

Berdasarkan hasil penelitian dapat disimpulkan bahwa tindakan perbaikan pembelajaran metode tugas telah mampu meningkatkan kemampuan menulis karangan berdasarkan pengalaman pada siswa kelas V SD Inpres 55 Kabupaten Sorong tahun pelajaran 2015/2016.

Peningkatan tampak pada nilai rata-rata ketuntasan perorangan siswa pada siklus I meningkat ke siklus II di atas KKM, dan peningkatan terjadi pada nilai rata-rata ketuntasan klasikal di atas KKM. Dalam kegiatan proses belajar mengajar suasana belajar juga tampak meningkat pada motivasi dan kerjasama dalam kelompok. Siswa merasa lebih senang dan nyaman. Peningkatan juga nampak pada perencanaan pelaksanaan pembelajaran guru dari siklus I ke siklus II yang dinyatakan lebih baik.

\subsection{Saran}

Dari hasi penelitian tindakan kelas ini, peneliti menyarankan untuk tindakn lebih lanjut sebagai berikut :

a) Agar guru bahasa Indonesia lebih kreatif memilih metode pembelajaran dalam meningkatkan pembelajran menulis karangan berdasarkan pengalaman

b) Agar guru lebih memperhatikan aspek siswa sebagai pusat pembelajaran dengan selalu memotivasi siswa agar lebih aktif dan kreatif.

\section{Daftar Pustaka}

Akhadiah, Saharti. 1991. Menulis. Jakarta : Depdikbud.

Arikunto, Suharsimi. 1996. Prosedur Penelitian Suatu Pendekatan Praktek. Bandung : Balai Pustaka.

Moeliono, Anton. 1995. Kamus Besar Bahasa Indonesia. Jakarta : Balai Pustaka.

Keraf, Goris. 1985. Karangan berdasarkan pengalaman dan Narasi. Jakarta : PT Gramedia

Martutik, Suparno. 1998. Wacana Bahasa Indonesia. Jakarta: Depdikbud.Jakarta : Depdikbud.

Soejono, Ag. 1993. Metodik Khusus Bahasa Indonesia. Bandung : Bina Karya.

Soenarji. 1998. Azas-azas Menulis. Semarang: IKIP Semarang Press.

Suhadi. 1996. Memenangkan lomba mengarang. Jakarta : Balai Pustaka

Sumardjo, Jakub. 1994. Apresiasi Kesusasteraan . Jakarta : PT Gramedia.

Tarigan, Djago. 1986. Menulis Sebagai Keterampilan Berbahasa. Bandung : Angkasa.

Usman, Uzer. 1990. Menjadi Guru Profesional. Bandung : Remaja Rosdakarya. 